\title{
"What Can the Whole World Be Hiding?": Exploring Africana Esotericisms in the American Soul-Blues Continuum
}

\author{
Hugh R. Page, Jr. and Stephen C. Finley
}

The essays in Esotericism in African American Religious Experience: "There is a Mystery" ... (Finley, Guillory and Page, 2015) inscribe the broad contours for trans-disciplinary examination of esoteric thought and practice in the Africana world. Having established the preliminary groundwork for a new field-Africana Esoteric Studies (AES) — the stage is set for exploration of the ways in which secrecy, concealment, and selective disclosure of information deemed essential for survival function within an array of African and AfricanDiasporan settings, particularly those that are part of the Atlantic World (on the nature of this area of cultural exchange, see the now classic treatment of Gilroy, 1993).

As is to be expected, much work remains to be done in articulating the boundaries and teasing out the methodological particularities for this new enterprise. Such must involve, but is certainly not limited to, offering suitably inclusive, yet non-essentialist, parameters for that part of the Africana milieu whose esoteric elements are embraced by AEs and clarifying the theoretical underpinnings of this trans-disciplinary enterprise. Another has to do with delimiting the relationship of AEs to the already established discipline of Western esotericism.

The current essay hopes further to advance this process by examining four issues: (1) by what criteria figures are deemed to be either creators or critics of the artifacts and lore constitutive of both Western esotericism and AES; (2) the discursive and experiential matrices within which theories of the esoteric have heretofore been articulated; (3) the role that visual and performing artists have played in the creation and promulgation of esoteric cosmologies; and (4) the extent to which more expansive methodological and hermeneutical paradigms may create space for the engagement of persons, movements, and ideational currents often considered peripheral in terms of their relationship to the Western esoteric mainstream. It will also offer an experimental paradigm for thinking about African-American esotericism, grounded in critical and aesthetic engagement of expressive culture.

The essay will utilize as historical touchstones several key foci of and contributors to Western esotericism as well as selected artists in the American 
Soul-Blues continuum of the late 196os to the early 1970s. The latter will be featured because of their creation, adaptation, or re-appropriation-during a period of remarkable civic unrest - of disparate sources in the fashioning of Africana esotericisms; and their social positioning as prophetic figures through which such traditions are disclosed, gate keepers hinting at the existence of alternative realities, creators of new Africana Weltanschauungen, and grassroots theorists. The essay will also use, as an illustrative model, an experimental interpretive method (flash non-fiction) for engaging selected African-American musical artists. Such will include the group Earth, Wind \& Fire, the refrain from whose song, "The World's a Masquerade," serves as inspiration for the title of this essay.

This investigation will be suggestive rather than exhaustive in scope. Two of its more important desired outcomes will be a deeper appreciation of: (1) the role that artists play as stewards, creators, and interpreters of esoterica in Western esotericism and AES; as well as (2) the ways in which signature artifacts and iconic performances become generators of context-specific Africana esoteric worldviews and the theories deployed in understanding them.

\section{1 \\ Prolegomenon—Epistemological, Theoretical, and Methodological Contestations}

Conversations about "Western esotericism" take one immediately into a fraught realm of contested nomenclature, both complementary and discordant methodologies, and competing notions about both the cultural phenomena being studied and the Sitze im Leben in which such work is conducted. The same can be said of recent efforts to interrogate Western esotericism critically and propose alternative approaches for studying esotericism in general. Evidence of such can be clearly seen in Wouter Hanegraaff's article on the history and global scope of esotericism (2015, p. 4). His arguments: in favor of maintaining the designation "Western esotericism" to describe a disparate range of "beliefs, practices, and traditions of knowledge that the Enlightenment has rejected in its own backyard" (p. 86); justifying the use of "Western" in reference to the historically situated epistemological domain in which the study of esotericism unfolds (p. 82); in support of research exploring the global diffusion of European esoteric traditions as well as studies that examine cultural phenomena and lore that "resist discursive language and logical analysis" (p. 87); and cautioning against forcing "traditional beliefs and practices" encountered throughout the world into the "Western category of 'esotericism"' (p. 86) are cogent-in some cases compelling — though not altogether convincing. 
One can reasonably take issue with any conceptualization of "Western esotericism" that defines it exclusively in terms of the materialistic and empirical norms of the Enlightenment. If one looks, for example, at the historical life settings of subaltern populations subject to acts of colonial violence and repression, tools of resistance were often - by nature and necessity — placed under a veil of secrecy. They became, thereby, part of an esoteric poetics and praxis of liberation. In an African-American context, this could encompass the symbols emblematic of escape encoded in Black Spirituals, way stations on the Underground Railroad, family recipes, traditions of land-keeping (Gundaker, 1998), or even the materia medica from indigenous systems of healing. Such ideas and practices were made necessary by the conditions of existence that made Black life in the United States precarious. Moreover, many other examples of secretly coded esoteric cultural artifacts were produced in African-American esoteric milieus, such as the Harlem Renaissance. African-American literary theorist, Jon Woodson, may be the leading scholar on this subject. Woodson has done the most extensive work, tracking and interpreting Harlem Renaissance literature as African-American esoteric interventions into European and American occult texts (Woodson, 1999, pp. 1-28).

Among Woodson's significant works on the subject of African-American esotericism are his book, To Make a New Race: Gurdjieff, Toomer, and the Harlem Renaissance (1999) and his chapter in Esotericism in African American Religious Experience: "There Is a Mystery"... entitled "The Harlem Renaissance as Esotericism: Black Oragean Modernism" (2014). Woodson contends that much of the literature that has come to represent the Harlem Renaissance was produced by a secret enclave of African-American esoteric intellectuals, led by writer Jean Toomer, but that included Zora Neal Hurston, Melvin Tolson, Nella Larson, Wallace Thurman, George Schuyler, Rudolph Fisher, and many other literary prodigies. These thinkers took European and American esoteric thought such as that of George Ivanovich Gurdjieff and occult leaders who studied his systems or who studied with him, such as Alfred Richard Orage and Pyotr Demianovich Ouspensky, and turned these esoteric systems into something uniquely African-American. In short, they utilized these thought systems - critiquing some of the racial animus that they found within themand transformed them into something that was not just contemplative but that had to be enacted; they required action, specifically with regard to race and racism. Indeed, while Toomer studied directly with Gurdjieff, the "Black esoteric underground," in the words of Hugh R. Page, Jr., of the Harlem Renaissance transmuted occult thought into revolutionary African-American literature that served to subvert the vicissitudes of racialized existence. This creative alteration of something pre-existing into something that differed qualitatively 
from its former state, which specifically served the intentions and purposes of African-American life, was one of the hallmarks of Africana culture in the United States. In some cases, African Americans took something that was used in service of their oppression, and flipped it, changing its meaning and function to something used to create new life worlds. Moreover, Africana esoteric thought was expansive since it was reflected in many other aspects of the movement, such as in the art of Aaron Douglas and the philosophical musings of Alain Locke.

Most of the aforementioned would not have been part of the "Global Dustbin of Rejected Knowledge" (Hanegraaff, 2015, p. 64), but many of them would have been perceived as implicitly threatening to those in Europe and the Americas whose power and wealth were enhanced by tools of empire building derived in part from Enlightenment science. Here, one could certainly include technologies used to subdue, imprison, transport, and commodify Africana bodies. Which is to say, new perspectives and approaches to the study of Western esotericism might well consider the importance of embodiment, which, heretofore, has not taken center stage because the disciplinary method has privileged historiography. The "dustbin of rejected knowledge," then, becomes strictly about excluded ideas (cf. Asprem, 2021). But what then of rejected bodies: people whose identities were created in the very processes of the West that yielded "rejected knowledge?" It is impossible to speak of Africana Esoteric Studies without giving serious consideration to the idea of "rejected people" whose knowledge was cast aside precisely because of their embodiment. Their knowledge about the world has been doubly concealed in this context; their "esotericism" has not historically registered as "rejected knowledge" within the discourses and schemes of Western esotericism and the West, more generally, while, at the same time, they have been forced to conceal and reveal selectively their Truths within intellectual and cultural worlds in which African-American "Truth" (capital "T") has been written and intellectualized as an impossibility across discursive and semiotic fields. This is an issue to which Finley, Guillory, and Page make reference in the opening chapter of Esotericism in African American Religious Experience (2015). Thus, black bodies were constituted as the esoteric of Western esotericism, the people most rejected in modernity, whose most meaningful ideas were relegated to the "dustbin" of the "dustbin" (cf. also Bakker, 2021).

Because blackness is ontologically mapped as surface, according to Philosopher George Yancy (2004, p. 9), rather than interiority, whose meaning is disbursed across its skin, black bodies were doubled, perhaps tripled, since to be black was and is already the quintessential rejection. To gloss Fanon's Black Skin, White Masks (1967, p. 112), the agential corporeal schema of black embodi- 
ment is reduced to and externalized as a racial epidermal schema, and, indeed, as Yancy notes "there is no apparent position of externality from which the black is able to negotiate his identity" (2004, p. 13). That is, within the West's discursive schemes and racial structures, blackness is ontologically frozen as inferior and mute, thereby rendering black critical thought unintelligible and illogical in Western intellectual frames of reference. This is why the maintenance of the category "Western" and all its historical and racial significations amounts to an epistemic consolidation of power that determines what knowledge is legitimate and what is not, what is apprehended and what remains obscured, and what is pure transcendence and what is externalized as immanence.

To this end, questions can be raised about Hanegraaff's methodologically grounded rationale for maintaining the use of the term "Western" to identify the intellectual domain in which so-called "rejected knowledge" (2015, p. 66) is engaged (cf. Strube, 2021). The same is true of his notion that esoteric realia are only made known to us "as specific products of Western culture" (p. 82). Ways of seeing, hearing, and knowing discarded by the West - and other epistemic discourses of empowerment created within the Africana (i.e., African and African-Diasporan) World—have often been curated according to canons and passed on via an assortment of media, some of which are hybrid and others that are neither European nor Western. Furthermore, those ideas and artifacts judged to be esoteric according to specifically African-American criteria are often understood as part of a legacy from an actual, imagined, or longed-for homeland, rather than as the fruit of cultural production in the West.

Tracey Hucks' Yoruba Traditions \& African American Religious Nationalism (2012) is most insightful here. This notion of a homeland, which animates many of the sources and realia that are used by and constitute Africana Esoteric Traditions (AETS) are not insignificant, and Hucks engages in a methodologically rich approach, which includes ethnography (necessary, since AETs often have no archive for historiography), to uncover and make sense of what Africana religions such as African-American or "African Diasporic" Yoruba religions are doing. Hucks also gives attention to religious groups like the Nation of Islam, whose ideas and practices have been greatly misunderstood in popular discourses. What she argues is that Africana religions' longing for a homeland is much more symbolic than political in the sense that such longings have religious rather than decidedly political intentions. To this end, such religious communities are not interested in becoming nation-states. Their quests for imagined or symbolic homelands have much more to do with experiences of displacement and otherness; these are communities that have been violated, marginalized, and separated from their actual and mythological origins. Thus, 
Africana religions re-imagine beginnings in service of new epistemologies and ontologies that would (re-)authenticate their humanity in a hostile world that often denied it.

Re-authentication is important for Hucks. While the site of religion allowed African Americans to create new realities, knowledge, and identities, these served-not as new per se-but as "reconnections" to cosmologies and mythologies that signified some original state of being that transcended their racialized existences in which the meanings of their bodies were formulated by others and thrust back at them as them. This could only result in an experience of alienation from their own bodies, which their own autonomous truth, to borrow a term from Charles $\mathrm{H}$. Long, would not allow them to recognize as themselves, but rather as the products of a racist and racializing western project. Re-imagining a homeland, thus, was a creative project of transcendence that afforded new ontologies and epistemologies in a world where there was no intimacy of knowledge of African-Americans, only a concretizing and distancing knowledge about them. African-Americans, then, were able to create new systems of knowledge, appropriating multiple sources including those that were discarded and abandoned in the West.

Regarding analysis of knowledge abandoned in the wake of the Enlightenment and diffused worldwide, such is crucial. One example would be the spread and reception of various forms of Freemasonry among African Americans beginning in the late eighteenth and early nineteenth centuries, including Prince Hall Freemasonry (Page, 2003). Furthermore, the embrace and adaptation of European esoteric traditions (e.g., Rosicrucian, Elus Cohens, and Martinist) in West African and Caribbean contexts offers opportunities to assess how such traditions were preserved and/or brought into conversation with philosophies and cosmologies indigenous to these regions.

Hanegraaff's caution to avoid "terminological imperialism" (2015, p. 86) is well taken. Imposing etic categories on phenomena for which emic taxonomies are available (if, at times, not readily accessible) is a danger in ethnographic description and comparison. Equally problematic, however, is the tendency toward claiming exclusive ownership of terms like esotericism, culture, religion, etc., by one or more academic disciplines; or insisting that research on them conform to an established set of methodological conventions or engage a specific body of secondary literature. For example, Hanegraaff objects to the way that the co-editors of Esotericism in African American Religious Experience define esotericism and what he considers their failure to engage, "twenty years of theoretical debate" (2015, p. 61n22). However, just as he provides his own definition of esotericism and selects those with whom he will be in conversation about its essential features-i.e., E.B. Tylor, Lucien Lévy-Bruhl, Carl 
Jung, Richard Wilhelm, and Antoine Faivre (2015, pp. 71-80)—do the aforementioned co-editors not have the right to define terms, establish methods, and determine those with whom they will engage in discussion? Moreover, the extent to which sustained and nuanced theoretical debate has been a cornerstone of Western esotericism to date is open to question. Paul Lawrence Dunbar, Zora Neale Hurston, Houston Baker, Kevin Young, and Helena Andrewsto name just a few-introduce us to a rich nomenclature of secrecy and hiddenness within Africana life in the North American Diaspora. Such includes Dunbar's nuanced understanding of masking, ${ }^{1}$ Hurston's interpretation of lying (see, for example, Hurston, 1990), Baker's notion of being "trained" (1984, pp. 8, 10), Young's conception of the "hiding tradition" (2012, p. 23), and Andrews' definition of "reserve" (2012, p. 37).

Moreover, Hanegraaff's contention that those luminaries studying beliefs that ran counter to Enlightenment thought did not hold that such traditions were confined to the West is worthy of note (2015, p. 70). However, the list of those he identifies as contributors to this scholarly conversation is somewhat narrow (e.g., Waite, Baumann, Magee, Otto, Granholm, Asprem, Strube, Godwin, Pasi, Partridge, Said, etc.) and excludes, for example, those paving the way for the establishment of AEs. He also corrects his own prior assumption about the racial homogeneity of those involved in esoteric activities (p. 6on21), given perspectives presented in the anthology edited by Finley, Guillory, and Page (2015).

\section{$2 \quad$ Toward a New Paradigm}

One wonders about the potential of context-specific and historically framed methodologies focusing on esotericism(s) in the Africana world: interventions that use as starting points artifacts and ideas derived from African and AfricanDiasporan life settings. Approaches of this kind can proceed from locally derived definitions of the esoteric and situate the concept within disparate Africana imaginaries; focus attention on those that create and/or curate esoteric lore from Africana and other cultural spaces; and offer readings (or, to use a concept from the work of Charles Long, "significations"; 1986, pp. 1-9) of the esoteric within and beyond Africana settings.

1 See his poem, "We Wear the Mask" - https://www.poetryfoundation.org/poems/44203/we -wear-the-mask (accessed July 29, 2020). 
The balance of this essay will be dedicated to one such experimental "signification," creative and critical in orientation, and an assessment of the potential impact of such interventions for the study of esotericism. Utilizing "flash non-fiction" (FNF), complemented by the second-person narration utilized to great effect by Claudia Rankine in Citizen: An American Lyric (2014), we offer a partial theoretical map for the esoteric topography of African-American music from the late 196os and early 1970s. Miller and Paola (2012, p. 110) describe FNF as a concise (1,000 words or less), lyrical, imaginative, targeted, and evocative narrative centering on a single theme or image. We proceed from the assumption that on occasion, esoteric realities are perhaps best explored through esoteric genres.

Not the Way It Is, but the Way “It Tiz ...”: An Africana Esoteric Signification

"Playlist" is one of many words in the twenty-first century lexicon you find endlessly fascinating. It conjures moments of cognitive dissonance. What have "play" and "list" to do with each other? Where is the supposed relationship to music? One might well "play" a song, or even read an album's inventory of "cuts." Listening, however, is an altogether different experience.

How far you've come from 45s, LPs, reel-to-reel recorders, 8-track players, and cassette tapes, some of which you still own and enjoy. You are neither an anachronism nor a Luddite. Neither are you a hoarder. You've come to appreciate the power-the àshe, as it were (Thompson, 1984, p. 5) -in old things. Even before you learned who he was, you've known that Amiri Baraka was right about African-American music containing the narrative of Black history (Jones, 1963, p. viii). Knowing that keeps you from discarding those vestiges of the Analog Era, on which ancestors and elders recorded our stories and encoded our secrets. You gather originals and re-mastered versions from Bob's Blues and Jazz Mart and other sanctuaries that traffic in the remnants of Africana culture (Reich, 2016). You mine the digital catalogues of iMusic and Pandora for albums and songs no longer easily accessible on other media. You return to them time and again, each encounter bringing with it new realizations. Each engagement reveals hidden truths to you, especially when you are capable of setting aside the "respectability politics" that once characterized Black creative expression as dangerous; and the Gospel as the only authoritative truth. You take Ben Harper's advice and "listen close to what you see" (1997). You heed James Blood Ulmer's admonition to "use the concept of the Blues to feel" your "way around" (2011). You "build" against convention like 
Erykah Badu in, "On and On" (1997), and trust that those with "ears to hear" (Deuteronomy 29:4; Mark 4:9-New Revised Standard Version of the Bible) will understand the "method to your madness," as some of the "old folk" say. It's fine if they don't get it. An old warning - "Tell some, keep some, you'll always have some"- has a chastening effect when you consider bringing those things that have kept us alive into the academy for intellectual dissection. The tradition keepers sensed that some things should never be shared.

"Back in the day," there was so much you didn't understand. Some knowledge was dangerous: so much so that it was only selectively disclosed to Black youth. Not knowing kept you from misreading the secrets "grown folk" talked about when they thought you weren't listening; or even from being killed. As you enter the generation of Black tradition keepers, you wonder about the seemingly boundless depths of their knowledge? In fact, you're still learning. Certain lore is only now being passed on to you. The good thing is that the community of those with interests like your own is growing and that the sharing of truths once hidden comes by means of the internet, articles, and books rather than via word-of-mouth alone. You marvel at the things revealed. You're "blown away" by their implications for understanding the Black World and the place underground ways of knowing occupy in it.

You realize that "La, la, la, la, la, la, la, la, la" meant much more than "I love you" (1968); that Thomas Bell and William Hart were strategically trafficking in "wordlessness"; and that Hart's falsetto vocals on Delfonics' songs were conjuring "Elsewhere." ${ }^{2}$ You can detect the not-so-subtle critiques of Black consumerism and conjure culture in the lyrics of the Temptations' "I Can't Get Next to You" (1969) and their topographical mapping of numinous revelatory loci beyond the doors of the Black Church in "Psychedelic Shack" (1970). You hear in the words of Undisputed Truth's "Smiling Faces Sometimes" (1969) poignant reservations about emotional masking and "reserve" (Andrews, 2012). You wonder about the deeper meanings that accrue to the teleological journey and final destination envisioned in the Staples Singers' "I'll Take You There" (1972) and are inspired to explore the relationship between mainstream epistemologies and esoteric ways of knowing by Earth, Wind \& Fire's "The World's a Masquerade" (1973). You wonder about the odd inter-textual discussion about Black life brokered by Blue Magic's performance of "Sideshow" (1974), the lyrics for which were co-authored by Robert Rivkin, Lisa Coleman, and Wendy Malvoin - none of whom are of African descent, but all of whom were members of the late Prince Rogers Nelson's backup band, "The Revolution."

2 On falsetto, elsewhere, and wordlessness, see Young (2012, pp. 52-53, 259-261). Young is, in a real sense, the esoteric docent through which these realizations were disclosed. 
You have a surprising sense of ennui. A Black world saturated with secretssome hidden virtually in plain sight and at times unknown even to Black mystagogues themselves-exists. Why has it taken so long to see, acknowledge, value, collect, and study them? Yours is a fetishized body in colonized space. Such activities are messy. They require you to embrace your hybrid identity as Africana elder, citizen of the Western academy, and provocateur; to challenge certain disciplinary orthodoxies; and even to blur the boundaries between scholarship and resistance. The poetics and potential outcomes of such acts are dangerous. This is one of those realities you've come to accept as normal. As the elders often say, "It be's like that" (on the meaning of which, see Major, 1994, p. 252). Or, as your contemporaries say, that's just "the way 'it tiz."

There has long been a tendency to view academic writing and scholarly performance as functions that were "hermetically sealed" (pun intended) from other realms of creative human endeavor, and to ascribe authority for development of the tools for meta-critical analysis to theoreticians purportedly situated at a safe distance from (and beyond the influence of) the phenomena they study. Approaches of this kind permit rather facile distinctions to be made between practitioners and scholars, broadly defined. They also lead to the relationship between power, privilege, and the construction of knowledge being insufficiently queried. This has potentially disastrous consequences for appreciating the complexity of some figures in the history of Western esotericisme.g., Hildegard von Bingen, Louis Claude de Saint-Martin, and Jakob Böhmewhose oeuvres defy singular categorization. It is equally problematic for understanding the formative influences on and contributions of individuals such as Paschal Beverly Randolph and Pamela Colman Smith, whose ideas can be productively viewed through the intersecting perspectives of Western esotericism and AES. It is completely untenable for de-colonial methodologies that take into consideration the social locations and biographies of researchers, expand the circle of interlocutors and topics engaged, and take seriously what might be termed "grassroots theorizing" about the nature of reality (cf. Villalba, 2021).

The FNF piece above narrates one de-colonial journey of AEs discovery. Central to it are a number of ethical issues, such as: what occurs when scholars within the Africana world use as starting points for their work tangible 
artifacts, ideas, taxonomies, and descriptive language from their immediate surroundings; factors contributing to the concealment of Africana epistemologies and their selective disclosure in academic settings; the utility of literary and performative genres - like FNF-in descriptive, analytical, and interpretive interventions that increase our understanding of various Africana esotericisms; and the important place that non-traditional conversation partnerse.g., community elders, tradition keepers, poets, musicians, etc.-occupy as creators, collectors, and curators of secret lore, particularly on the American side of the Black Atlantic.

AES creates space for this kind of work, which holds great promise for understanding the local histories and traditions governing the concealment and selective disclosure of cultural traditions and practices. The seven songs from the Soul-Blues continuum constituting touchstones for this essay provide evidence of a rich conversation about the particularities of African-American survival in the late 196os and early 1970 os and navigating a fraught social landscape in which all things Black were considered as radical expressions of alterity in the West.

This essay - and the experimental FNF foray therein-is, in a manner of speaking, an effort to re-signify scholarship in AES as a radically self-conscious and emancipatory enterprise in which the cultural realia of the colonized are subject to a non-exploitative subaltern "gaze." Here, one thinks immediately of the role that songwriters and lyricists such as Thomas Bell, William Hart, Norman Whitfield, Sr., Norman Whitfield, Jr., Barrett Strong, Alvertis Bell, and Clarence "Skip" Scarborough — whose works were engaged directly in the aforementioned FNF piece-played in this process. It is, by intent, nontotalizing and partially obfuscating. Unlike projects such as the Dictionary of Gnosis and Western Esotericism (Hanegraaff et al., 2005), it in no way purports to be "comprehensive" (ibid., p. vii). Instead, keeping in mind the implicit dangers associated with academic disclosure, it compels readers to search for and engage persons, concepts, and themes considered, by and large, absent from or tangential to Western esotericism. Our hope is that this essay will further establish inclusive parameters for creative interventions that shed light on the varieties of esotericism in the Africana world.

\section{Bibliography}

\section{Songs Referred to in This Study}

"La La Means I Love You" · Performed by "The Delphonics" · Songwriters—Thomas Bell \& William Hart (1968) 
"I Can't Get Next to You" - Performed by "The Temptations" · Songwriters-Strong, Whitfield, and Whitfield (1969)

"Psychedelic Shack" • Performed by "The Temptations" · Songwriters-Strong, Whitfield, \& Whitfield, Jr. (1970)

"Smiling Faces Sometimes" · Performed by "The Undisputed Truth" · SongwritersStrong \& Whitfield (1971)

"I'll Take You There" • Performed by "The Staples Singers" • Songwriter-Alvertis Bell (1972)

"The World's a Masquerade" · Performed by "Earth, Wind \& Fire" · SongwriterClarence "Skip" Scarborough (1973)

"Sideshow" · Performed by "Blue Magic" · Songwriters—-Robert Rivkin, Lisa Coleman, and Wendy Malvoin (1974)

\section{References}

Andrews, H. (2012) "Reserve," in Walker, R. (ed.) Black Cool: One Thousand Streams of Blackness. Berkeley, CA: Soft Skull Press, pp. 29-38.

Asprem, E. (2021) "Rejected Knowledge Reconsidered: Some Methodological Notes on Esotericism and Marginality," in Asprem, E. and Strube, J. (eds.) New Approaches to the Study of Esotericism. Leiden and Boston: Brill, pp. 127-146.

Badu, E. (1997) Baduizm. New York, NY: Universal Records.

Baker, H., Jr., (1984) Blues, Ideology, and Afro-American Literature. Chicago, IL: University of Chicago Press.

Bakker, J.M. (2021) "Race and (the Study of) Esotericism," in Asprem, E. and Strube, J. (eds.) New Approaches to the Study of Esotericism. Leiden and Boston: Brill, pp. 147-167.

Blue Magic (1974) "Sideshow," Blue Magic. New York, NY: Atco.

Delfonics (1968) "La-La-Means I Love You," Philadelphia, PA. Philly Groove Records.

Earth, Wind \& Fire 1973, "The World's a Masquerade," Head to the Sky. New York, NY: Columbia Records.

Fanon, F. (1967) Black Skin, White Masks. New York, NY: Grove Press.

Finley, S., Guillory, M., and Page, H.R., Jr. (eds.) (2015) Esotericism in African American Religious Experience: “There is a Mystery” ... Leiden: E.J. Brill.

Gilroy, P. (1993) The Black Atlantic: Modernity and Double Consciousness. Cambridge, MA: Harvard University Press.

Gundaker, G. (ed.) (1998) Keep Your Head to the Sky: Interpreting African American Home Ground. Charlottesville, VA: University Press of Virginia.

Hanegraaff, W.J. (2015) “The Globalization of Esotericism," Correspondences, 3, pp. 5591.

Hanegraaff, W.J., Faivre, A., Broek, R.v.d., and Brach, J.-P. (eds.) (2005) Dictionary of Gnosis and Western Esotericism. Leiden/Boston: E.J. Brill. 
Harper, B. (1997) "Jah Work," The Will to Live. Virgin Records America, Inc.

Hucks, T.E. (2012) Yoruba Traditions \& African American Religious Nationalism. Albuquerque, NM: University of New Mexico Press.

Hurston, Z.N. (1990) Mules and Men. Reprint of 1935 edn. New York: HarperPerennial.

Jones, L. (1963) Blues People: The Negro Experience in America and the Music that Developed from It. New York, NY: Morrow.

Long, C. (1986) Significations: Signs, Symbols, and Images in the Interpretation of Religion. Minneapolis: Fortress Press.

Major, C. (1994) Juba to Jive: A Dictionary of African-American Slang. New York, NY: Penguin.

Miller, B. and S. Paola. (2012) Tell it Slant: Creating, Refining, and Publishing Creative Nonfiction. 2nd ed. New York: McGraw Hill.

Page, H.R., Jr. (2003) "A Case Study in Eighteenth-Century Afrodiasporan Biblical Hermeneutics and Historiography: The Masonic Charges of Prince Hall," in Bailey, R.C. (ed.) Yet With A Steady Beat: Contemporary U.S. Afrocentric Biblical Interpretation Semeia Studies. Atlanta: Society of Biblical Literature, pp. 103-122.

Rankine, C. (2014) Citizen: An American Lyric. Minneapolis, MN: Graywolf.

Reich, H. (2016) "Jazz Record Mart's Bob Koester Celebrates 84th Birthday and a New Store," Chicago Tribune(November 1, 2016), https://www.chicagotribune.com/entert ainment/music/howard-reich/ct-jazz-mart-bob-koester-record-store-ent-1102-2016 11o1-column.html. Available at: https:/www.chicagotribune.com/entertainment/ music/howard-reich/ct-jazz-mart-bob-koester-record-store-ent-1102-201611o1-colu mn.html (Accessed July 29, 2020).

Strube, J. (2021) “Towards the Study of Esotericism without the 'Western'”: Esotericism from the Perspective of a Global Religious History," in Asprem, E. and Strube, J. (eds.) New Approaches to the Study of Esotericism. Leiden and Boston: Brill, pp. $45^{-66 .}$

Temptations (1969) "I Can’t Get Next to You," Detroit, MI: Hitsville USA.

Temptations (1970) Psychedelic Shack. Motown Records.

The Staples Singers (1972) I'll Take You There. Memphis, TN: Stax Records.

Thompson, R.F. (1984) Flash of the Spirit: African and Afro-American Art and Philosophy. 1st Vintage Books edn. New York, NY: Vintage Books.

Ulmer, J.B. (2011) There is Power in the Blues. Greatest Blues Hits. Hyena.

Undisputed Truth (1969) "Smiling Faces," Detroit, MI: Motown.

Villalba, M. (2021) "The Occult Among the Aborigines of South America? Some Remarks on Race, Coloniality, and the West in the Study of Esotericism," in Asprem, E. and Strube, J. (eds.) New Approaches to the Study of Esotericism. Leiden and Boston: Brill, pp. 88-108.

Woodson, J. (1999) To Make a New Race: Gurdjieff, Toomer, and the Harlem Renaissance. Jackson, MS: University of Mississippi Press. 
Woodson, J. (2014) "The Harlem Renaissance as Esotericism: Black Oragean Modernism," in Finley, S., Guillory, M.S. and Page, H.R., Jr. (eds.) Esotericism in African American Religious Experience: "There is a Mystery”... Leiden: E.J. Brill, pp. 102-122.

Yancy, G. (ed.) (2004) What White Looks Like: African American Philosophers on the Whiteness Question. New York, NY and London, UK: Routledge.

Young, K. (2012) The Grey Album. Minneapolis, MN: Graywolf. 